\title{
CEGAH KANKER SERVIKS DENGAN CERDIK
}

\author{
Yuyun wahyuni \\ Mahasiswa Institut Ilmu Kesehatan STRADA Indonesia, Prodi Sarjana Kesehatan Masyarakat \\ Email : yuyunwyuni146@gmail.com
}

\begin{abstract}
Abstrak
Kanker serviks merupakan kanker peringkat kedua yang paling banyak di Indonesia setelah kanker payudara. Jumlah kematian akibat kanker serviks di Indonesia terus meningkat setiap tahunnya yang disebabkan oleh keterlambatan melakukan diagnosis dan pemeriksaan. Rata-rata $70 \%$ ditemukan pada stadium lanjut. Keadaan ini disebabkan karena masih rendahnya tingkat pengetahuan masyarakat terkait kanker serviks, masih banyak penderita yang mencari perawatan tradisional dan alternatif, kurangnya perlindungan finansial, kurangnya pengetahuan tentang gejala umum dan tanda-tanda kanker di kalangan masyarakat. Salah satu upaya yang dapat dilakukan untuk menyikapi hal tersebut adalah melalui pendekatan kesehatan masyarakat Artikel ini membahas berbagai hal tentang pengertian, penyebab, gejala, faktor resiko kanker serviks, dan upaya pendekatan kepada masyarakat yang difokuskan pada intervensi perubahan perilaku melalui penerapan Hidup CERDIK yakni Cek kesehatan secara rutin melalui IVA tes, pencegahan imunisasi HPV, Enyahkan asap rokok, Rajin aktifitas fisik, Diet sehat dengan kalori seimbang, Istirahat cukup, dan Kelola stress.
\end{abstract}

Kata Kunci : Kanker serviks, pencegahan

\section{PENDAHULUAN}

Kanker serviks merupakan salah satu masalah utama pada kesehatan perempuan di dunia, terutama pada negara bekembang seperti di Indonesia. Alasan utama meningkatnya kanker tersebut di negara berkembang adalah karena kurangnya program penapisan yang efektif dengan tujuan untuk mendeteksi keadaan prakanker maupun kanker pada stadium dini.

Menurut data Globocan, saat ini beban penyakit kanker di dunia meningkat, yaitu terdapat 18,1 juta kasus baru dengan angka kematian sebesar 9,6 juta kematian di tahun 2018 dimana 1 dari 5 laki-laki dan 1 dari 6 perempuan di dunia mengalami kejadian kanker, serta 1 dari 8 laki-laki dan 1 dari 11 perempuan meninggal karena kanker (WHO, 2018).

Hasil rekapitulasi deteksi dini kanker serviks dengan metode IVA didapatkan 77.969 orang positif ca serviks. Provinsi tertinggi yang menderita kanker serviks di provinsi
Jawa Tengah sebanyak 25.300 orang, sedangakan provinsi Jawa Timur menempati urutan kedua yakni, sebanyak 18,515 orang ( Kemenkes RI, 2019).

Kanker serviks merupakan kanker peringkat kedua yang paling banyak di Indonesia setelah kanker payudara. Jumlah kematian akibat kanker serviks di Indonesia terus meningkat setiap tahunnya yang disebabkan oleh keterlambatan melakukan diagnosis dan pemeriksaan. Meningkatnya kasus kanker serviks dapat menambah beban masyrakat dan pemerintah. Untuk itu, dibutuhkan komitmen bersama dalam menurunkan morbiditas dan mortalitas akibat kanker serviks. Meningkatkan usaha promotif dan preventif agar meminimalkan terlambat deteksinya pada stadium lanjut. Pada stadium awal kanker serviks bisa sembuh dengan operasi atau krioterapi (P2PTM, 2019). 
Pencegahan primer lebih efektif dalam pengendalian kanker serviks tujuannya untuk mencapai Indonesia Sehat.

Setiap wanita berisiko terkena kanker serviks apabila memiliki pola hidup yang tidak sehat misalnya bergantiganti pasangan dalam berhubungan seksual, merokok aktif maupun pasif. Diperlukan upaya untuk meningaktkan kemandirian masyarakat melalui penerapan budaya perilaku CERDIK.

Kegiatan tersebut merupakan upaya agar memberdayakan masyarakat agar peduli dan menjaga kesehatan dan meningkatkan perilaku sehat individu masing-masing melalui perilaku CERDIK yaitu Cek kesehatan berkala dengan deteksi dini kanker melalui pemeriksaan IVA atau papsmear serta ditambah pelindungan dengan melakukan imunisasi HPV, Enyahkan asap rokok, Rajin olahraga, Diet yang seimbang, Istirahat cukup, serta Kelola stress.

\section{BAGIAN INTI}

\subsection{Pengertian Kanker Serviks}

Serviks adalah organ yang menghubungkan rahim dan vagina. Kanker merupakan penyakit yang disebabkan oleh pertumbuhan sel-sel tubuh yang tidak normal (Nurwijaya dkk, 2010)

Kanker leher rahim adalah keganasan yang terjadi pada mulut rahim (leher rahim) yang merupakan bagian terendah dari rahim yang menonjol ke puncak liang senggama /vagina (Nurwijaya dkk, 2010)

\subsection{Penyebab kanker serviks}

Penyebab utama kanker serviks adalah infeksi HPV (Human Papiloma Virus). Tipe HPV 16 dan 18 sebagai penyebab kasus keganasan di serviks/leher rahim wanita ( Handayani dkk, 2012). Penelitian telah membuktikan penyebab kanker servik adalah HPV tipe 16 (Chen \& Yeager, 2019)

\subsection{Gejala kanker serviks}

Menurut P2PTM 2019, Gejala kanker serviks meliputi:

a. Seringkali tidak menunjukkan gejala atau tanda yang khas.

b. Keputihan, pendarahan sesudah senggama perlu dicurigai sebagai gejala

c. Gejala pada tingkat lanjut sering:

1) Haid tidak normal

2) Perdarahan tidak pada masa haid

3) Perdarahan pada masa menopause

4) Keputihan atau keluar cairan encer putih kekuningan terkadang bercampur darah seperti nanah.

\subsection{Faktor resiko kanker serviks}

Faktor risiko terjadinya kanker leher rahim meliputi (P2PTM, 2019):

a. Melakukan hubungan seks diusia muda $<18$ tahun

b. Berganti-ganti pasangan seks

c. Melakukan hubungan seks dengan pria yang sering berganti ganti pasangan

d. Merokok atau terpapar asap rokok (perokok pasif)

e. Kurang menjaga kebersihan kelamin 


\subsection{Upaya pencegahan dengan CERDIK}

\subsubsection{Cek Kesehatan secara rutin}

Ada beberapa metode yang dikenal untuk melakukan skrining Kanker Leher Rahim. Tujuan skrining untuk menemukan lesi prakanker. Beberapa metode itu antara lain:

1. Inspeksi Visual dengan Aplikasi Asam Asetat (IVA) Pemeriksaan dengan cara mengamati dengan menggunakan spekulum, melihat leher rahim yang telah dipulas dengan asam asetat atau asam cuka (3-5\%). Pada lesi prakanker akan menampilkan warna bercak putih yang disebut acetowhite epitelium.

Sangat penting bagi wanita untuk melakukan tes IVA atau Papsmear secara rutin guna menangkap sel prakanker dan mencegah perkembangan kanker serviks (P2PTM, 2013).

2. Pemeriksaan Sitologi

(Papanicolaou/Papsmear)

Merupakan suatu prosedur pemeriksaan sederhana melalui pemeriksaan sitopatologi, yang dilakukan dengan tujuan untuk menemukan perubahan morfologis dari sel-sel epitel leher rahim yang ditemukan pada keadaan prakanker dan kanker (P2PTM, 2019).

Sangat penting bagi wanita untuk melakukan tes IVA atau Papsmear secara rutin guna menangkap sel pra-kanker dan mencegah perkembangan kanker serviks (P2PTM, 2013).

Apabila hasil pemeriksaan positif (stadium awal) dilakukan terapi dini krioterapi. Krioterapi merupakan metoda rawat jalan untuk menghancurkan jaringan dengan cara membekukan selsel menggunakan gas $\mathrm{CO} 2$ atau $\mathrm{N} 2 \mathrm{O}$ cair. Kelebihan krioterapi antara lain sangat efektif untuk mengobati lesi derajat rendah (CIN I) dan derajat tinggi (CIN II-III), mempunyai tingkat komplikasi rendah, tidak memerlukan anestesi, tidak membutuhkan listrik, mudah digunakan, serta tidak mahal (P2PTM, 2019).

Hasil terapi lesi prakanker serviks dengan krioterapi atau cold coagulation relatifsama, hal ini dibuktikan dengan masing-masing terapi telah mengubah 4 dari 5 pasien dengan IVA positif menjadi IVA negatif. Efek samping minimal dirasakan responden pada 1 bulan pasca pengobatan, sedangkan tidak ada efek samping yang dirasakan setelah 6 bulan pengobatan pascaterapi.(Laila Nurana, Nessyah fatahan, 2019).

Pencegahan dengan meningkatkan antibodi melalui imunisasi HPV (Human Papilloma Virus). Imunisai HPV sangat efektif untuk mencegah HPV sehingga imunisasi HPV dapat dijadikan sebagai program imunisasi nasional (Markowitz, Drolet, Perez, Jit, \& Brisson, 2018)

\subsubsection{Enyahkan Asap Rokok}

Ditemukan adanya hubungan yang signifikan secara statistiK antaa perokok pasif dengan kejadian kanker serviks. Wanita perokok pasif akan mengalami kanker serviks ,11,5 kali dibandingkan bukan perokok pasif (Amar, 2012)

Seorang perokok pasif yang terpapar asap rokok akan mengalami penurunan sistem imun untuk melawan virus HPV dan akan menyebabkan terjadinya kanker serviks. Dalam penelitian didapatkan kelainan tes pap pada wanita yang terkena paparan asap rokok terjadi kelainan sitologi yang menyebabkan hilangnya sistem imun nonspesifik. Pada sitologi serviks yang abnormal jumlah sitokin menurun yang dapat menyebabkan penurunan pembentukan sel $\mathrm{T}$ (Ward et al, 2011)

\subsubsection{Rajin olah raga}

Melakukan aktifitas fisik minimal 30 menit, jenis aktifitas fisik yang dapat dilakukan kegiatan sehari-hari seperti 
berjalan kaki, mencuci pakaian mengepel, dan sebagainya. Olahraga seperti Push up, lari ringan, bermain bola, senam dan sebagainya.

\subsubsection{Dietlah yang seimbang}

Susunan pangan sehari-hari yang mengandung zat gizi dalam jenis dan jumlah yang sesuai dengan kebutuhan tubuh. Menjaga pola makan disesuiakan dengan isi piringku

\subsubsection{Istirahat cukup}

Menjaga pola istirahat yang dianjurkan untuk orang dewasa 7-8 jam sehari.

\subsubsection{Kelola stress}

Mengelola pikiran yang positif , meditasi, yoga

\subsection{Peran serta Masyrakat dan dinas kesehatan kab/kota dan Puskesmas terkait pencegahan Kanker Serviks}

\footnotetext{
Pengelola Program Kab/Kota dan Pengelola Program Puskesmas menetapkan target dan sasaran di satu wilayah. Penetapan sasaran menggunakan data wanita usia 30-50 tahun atau wanita yang pernah berhubungan seksual. melakukan sosialisasi kepada target untuk mau mendatangi Fasilitas Kesehatan Tingkat Pertama (FKTP) melakukan deteksi dini kanker, promosi dan edukasi perilaku CERDIK, memastikan ketersediaan tenaga terlatih sebagai pelaksana memonitoring Posbindu PTM dan pembentukan kader Posbindu (P2PTM, 2019). Masyarakat diharapkan mengetahui, memahami serta berperan dalam gerakan CERDIK.
}

\section{KESIMPULAN}

Berdasarkan hasil pemaparan pembahasan mengenai pencegahan kanker serviks, dapat disimpulkan sebagai berikut:

1. Kanker seviks merupakan kanker yang bisa dicegah, diperlukan komitmen bersama dalam menurunkan morbiditas dan mortalitas akibat kanker serviks. Meningkatkan usaha promotif dan preventif agar meminimalkan terlambat deteksinya pada stadium lanjut.

2. Meningaktkan kemandirian masyarakat melalui penerapan budaya perilaku CERDIK. kegiatan tersebut merupakan upaya agar memberdayakan masyarakat agar peduli dan menjaga kesehatan dan meningkatkan perilaku sehat individu masing-masing melalui perilaku CERDIK

3. Kanker serviks disebabkan Human Papilloma Virusdapat dicegah dengan CERDIK yakni Cek kesehatan secara rutin melalui IVA tes, pencegahan imunisasi HPV, Enyahkan asap rokok, Rajin aktifitas fisik, Diet sehat dengan kalori seimbang, Istirahat cukup, dan Kelola stress

\section{DAFTAR PUSTAKA}

Amar, Syahmi. 2012. Hubungan Perokok Pasif Dengan Tingkat Kejadian Kanker Serviks Di RSUD Dr. Moewardi. Skripsi Fakultas Kedokteran Universitas Sebelas Maret Surakarta.

Handayani, dkk. 2012. Menaklukkan Kanker Serviks dan Kanker Payudara Dengan 3 Terapi Alami. Jakarta: ArgoMdia Pustaka.

Kemenkes RI. 2018. Profil Kesehtan Indonesia 2018. 
Nurwijaya, dkk. 2010. Cegah dan Deteksi Kanker Serviks. Jakarta: PT Gramedia.

P2PTM. 2019. Buku Pintar Kader Posbindu. Kementrian Kesehatan Repuplik Indonesia: Direktorat Pencegahan dan Pengendalian Penyakit Tidak Menular.

P2PTM. 2019. Buku Pedoman Manajemen Penyakit Tidak Menular. Kementrian Kesehatan Repuplik Indonesia: Direktorat Pencegahan dan Pengendalian Penyakit Tidak Menular.

P2PTM. 2013. Pedoman teknis Pengendalian Kanker Leher Rahim. Kementrian Kesehatan Repuplik Indonesia: Direktorat Pencegahan dan Pengendalian Penyakit Tidak Menular.

Chen, Z., \& Yeager, M. (2019). Human Papillomavirus 16 sub-lineage dispersal and cervical cancer risk worldwide: whole viral genome sequences from 7116 HPV16positive women Papillomavirus Research Human papillomavirus 16 sub-lineage dispersal and cervical cancer risk worldwide: Whole. ScienceDirect, (June). https://doi.org/10.1016/j.pvr.2019.02 .001

Laila Nurana, Nessyah fatahan, A. L. (2019). Cryotherapy versus Cold Coagulation for Treating Cervical Precancerous Lesions. Department Obstetrics and Gynecology Faculty of Medicine Universitas Indonesia Dr. Cipto Mangunkusumo General Hospital Jakarta, 7(4).

Markowitz, L. E., Drolet, M., Perez, N., Jit, M., \& Brisson, M. (2018). Human papillomavirus vaccine effectiveness by number of doses: Systematic review of data from national immunization programs. Vaccine, 36(32), 4806-4815. https://doi.org/10.1016/j.vaccine.201 8.01 .057

Markowitz, L. E., Drolet, M., Perez, N., Jit, M., \& Brisson, M. (2018). Human papillomavirus vaccine effectiveness by number of doses : Systematic review of data from national immunization programs. Vaccine, 36(32), 4806-4815. https://doi.org/10.1016/j.vaccine.20 18.01.057

https://www.google.com/url?sa=t\&source= web\&rct=i\&url=https://gco.iarc.fr/today/d ata/factsheets/populations/360-indonesiafact-sheets. pdf\&ved=2ahUKEwjLk-2f7$7 \mathrm{mAhXYeisKHfEBAn8QFjABegQICBAB \& \text {usg } =}$ AOvVaw2CxCbX3oRrh0RQ7oChcOBe diunduh tanggal 28 Desember 2019 WHO 2018

Sodik, M. A. (2018). Merokok \& Bahayanya. 
